\title{
Comparison of gingivectomy procedures for patient satisfaction: Conventional and diode laser surgery ${ }^{*}$
}

\author{
Elif Öncü ${ }^{\alpha}$, Ahmet Afşin Erbeyoğlu ${ }^{\alpha}$, Raif Alan $^{\alpha}$
}

Selcuk Dent J, 2017; 4: 6-9

Başvuru Tarihi: 09 Aralık 2016 Yayına Kabul Tarihi: 23 Şubat 2017

\begin{abstract}
Comparison of gingivectomy procedures for patient satisfaction: Conventional and diode laser surgery
\end{abstract}

Background: To compare the use of the $940 \mathrm{~nm}$ diode laser with conventional surgery in the management of soft tissue in gingivectomy procedures in terms of patient satisfaction.

Methods: This controlled clinical trial was conducted on 20 healthy patients who needing esthetic-only gingivectomy in the anterior maxilla. The patients were randomly divided into two groups of 10 each: experimental (diode laser-assisted surgery) and control (traditional surgery using scalpels). The bleeding rate following the surgery was assessed using the bleeding criteria established by the World Health Organization. The postsurgical discomfort level was recorded using visual analog scales (VAS), surgery time was evaluated for each operation and postoperative analgesic requirements were evaluated and compared.

Results: In control groups, anesthesia requirements were found statistically higher during surgery $(p<0.001)$. The average bleeding rates were 1.32 and 0.24 in the conventional and laser groups, respectively $(p<0.001)$. Experimental patients had no postsurgical pain but in the control group, VAS pain level was found higher. The difference between VAS values in each groups were significant $(p<0.001)$. There was no significant difference for surgery time between the treatment type.

Conclusion: This study shows that the diode laser has a great advantage over conventional surgery in the gingivectomy procedures.

\section{KEYWORDS}

Anesthesia, gingivectomy, lasers, semiconductor, visual analog scale

The gingival enlargement observed may be localized or generalized and is an inflammatory response that occurs when increase plaque accumulates on the teeth. This is a result of the patient not accomplishing effective oral hygiene. ${ }^{1}$ Whereas, this condition usually resolves with initial periodontal treatment and effective oral hygiene practices. But sometimes we may need to do more advanced treatments for a good aesthetic appearance. ${ }^{1,2}$ In these cases, the gingival margin needs recontouring via gingivectomy procedures. ${ }^{3}$
Öz

Konvansiyonel ve diyot lazer ile yapılan gingivektomi prosedürlerinin hasta memnuniyeti açısından karşılaştırılması

Amaç: Gingivektomi cerrahisinde konvansiyonel cerrahi veya 940 $\mathrm{nm}$ diyot lazer kullanımının hasta memnuniyeti açısından karşılaştırmaktır.

Gereç ve Yöntemler: Bu kontrollü klinik çalışma, anterior maksilla bölgesinde sadece estetik nedenlerle gingivektomi cerrahisi isteyen 20 sağlıklı hasta üzerinde yürütüldü. Hastalar her grupta 10 hasta olacak şekilde rastgele dağıtıldı. Test grubunda diyot lazer ile cerrahi uygulanırken, kontrol grubunda cerrahi işlem bisturi ile uygulandı. Ameliyat sonrası kanama oranı, Dünya Sağlık Örgütü tarafından belirlenen kanama kriterleri kullanılarak değerlendirildi. Ameliyat sonrası rahatsızlık düzeyi görsel analog skala (VAS) kullanılarak kaydedildi, ameliyat süresi her operasyon için değerlendirildi ve postoperatif analjezik gereklilikler değerlendirilip karşılaştırıldı.

Bulgular: Kontrol grubunda cerrahi sırasında anestezi gereksinimi istatistiksel olarak daha yüksek bulundu $(p<0.001)$. Ortalama kanama oranları, konvansiyonel ve lazer gruplarında sırasıyla 1.32 ve 0.24 idi $(p<0.001)$. Test grubundaki hastalarda cerrahi sonrası ağrı yoktu, ancak kontrol grubunda VAS ağrı düzeyi yüksek bulundu ve değerler arasındaki fark istatistiksel olarak anlamlıydı $(p<0.001)$. Gruplar arası ameliyat süreleri açısından istatistiksel olarak anlamlı bir fark bulunmadı.

Sonuç: Bu çalışmanın sonuçları doğrultusunda, diyot lazer ile yapılan gingivektomi prosedürlerinin konvansiyonel tekniklere göre bariz avantajları bulunduğu gözlenmiştir.

\section{ANAHTAR KELIMELER}

Anestezi, gingivektomi, lazerler, yarı iletken, görsel analog ağrı skalası

Gingivectomy can be performed by different methods such as scalpels, electrosurgery, chemosurgery, and laser. The conventional surgery performed by a scalpel which has been used the most common method. However, the long healing time and postsurgical high level pain of this treatment may cause patient discomfort with conventional gingivectomy procedures. ${ }^{4}$ Pain is one of the most important and common postoperative complications, that may intolerance on the patient for the surgical quality. ${ }^{5}$ Other

\footnotetext{
* Daha önce bu çalışma 04-06 Aralık 2015 tarihinde TPD 2015‘te tebliğ olarak sunulmuştur.

${ }^{\alpha}$ Necmettin Erbakan Üniversitesi Diş Hekimliği Fakültesi Periodontoloji Anabilim Dalı, Konya
} 
important side effect for conventional gingivectomy procedure is excessive bleeding during the operation. ${ }^{1,6}$ This bleeding prevent the convenience of the physician and success of operation. ${ }^{6}$

Gingivectomy can be performed easily with or without anesthesia with diode laser. ${ }^{6,7}$ Diode lasers can be provide hemostasis, less postoperative pain and swelling reduce the infection risk, and may improve aesthetics and accelerate recovery time while soft tissue healing. ${ }^{7,9}$ Laser therapy provides patient acceptance. ${ }^{10}$

Although several wavelengths may be used to treated inflamed gingiva or hyperplasic soft tissues with a very high vascular component, the use of near or far infrared laser is suitable. ${ }^{11}$ Diode laser is a nearinfrared type laser which with a wavelength ranging from $800 \mathrm{~nm}$ to $980 \mathrm{~nm} .^{12}$ All laser wavelengths are suitable for gingivectomy procedure but it is always important to use the correct wavelength for the specific tissue biotype..$^{13} 810 \mathrm{~nm}$ diode lasers have a very gentle incision procedure in soft tissue with cutting depth 2-6 mm. ${ }^{14}$ Diode laser have a very good surgical and hemostatic action on soft tissues following frenectomies, crown lengthening and recontouring of gingival enlargement. ${ }^{12-14}$

When perusing the literature it was found the lack of any studies comparing diode laser with conventional surgery procedure in gingivectomies in adult patient, because we found a few article that only about pediatric patients receiving orthodontic treatment. ${ }^{15-17}$ In this study it was aimed to compare the effects of $940 \mathrm{~nm}$ diode laser with conventional scalpel surgery on postoperative bleeding, pain and in patient satisfaction in adult patients needing cosmetic smile appearance with gingivectomy.

\section{MATERIAL AND METHODS}

The controlled clinical trial was made on 20 patients ( 8 male, 12 female), who were treated at the Department of Periodontology, Faculty of Dentistry, University of Necmettin Erbakan, Turkey, screened for eligibility to participate in this study. All of the selected patients gave full written informed consent in accordance with the Helsinki Declaration, and the Ethics Committee of Turkey approved the study protocol.

The patients included those who are periodontal healthy, and needing esthetic smile lift and did not have any systemic health problems. The exclusion criteria were any kind of periodontal diseases, bleeding on probing, smoking habits and poor oral hygiene (patients with plaque index value $\geq 1$, smoking habits and history of systemic diseases or any kind of disorders that could affect bleeding and pain perception directly).

The patients were randomly separated by toss coin method into two groups of control (10 subjects treated with the conventional surgery) and experimental (10 subjects treated with diode laser gingivectomy). All patients received oral hygiene instructions and phase I periodontal therapy at the beginning of the study. After 1 month, the physiological gingival contours of the patients were evaluated for gingivectomy requirements.

\section{Surgery}

In the control (conventional surgery) group, topical anesthetic was applied before surgery and it was not enough to deep anesthesia for patients. The surgical operations were carried out with local infiltration anesthesia (Ultracaine D-S ${ }^{\circledR}$, Sanofi Aventis, Germany). The surgeon asked the patient repeatedly that there is a feeling of pain for make sure that the operation was carried out under accurate anesthesia conditions. In the laser group, the local anesthesia was performed by only topical spray. In the laser group, no patient needed to extra anesthesia.

The conventional surgery performed by a standard surgical scalpel (Carbon, No.15) and gingivectomy blade (Hu Friedy 15/16, Chicago, USA). In control group, conventional gingivectomy was made with scalloped external bevel incision and then, a sulcular incision was performed with an Orban knife (Hue Friedy $1 / 2$, Chicago, USA). Following excision of the enlarged tissue with curettes, gingivoplasty was performed by Kirkland knife.

In the laser group, patients were treated for 30 second per tooth by a $940 \mathrm{~nm}$ diode laser (Diode Epic, BioLase, California, USA) with a $400 \mu \mathrm{m}$ fiber at $0,9 \mathrm{~W}$ power. During the laser gingivectomy, the laser tip move horizontally with a continuous laser beam, the gingival tissue was removed and formed. Periodontal dressings were used and the patients were prescribed flurbiprofen as needed for analgesia.

One month after the operation, five patients, from each groups, received restorative therapy after crown lengthening.

\section{Bleeding and pain determination}

Intra and postoperative bleeding were determined by the World Health Organization (WHO) bleeding scale. ${ }_{17,18}$ The amount of bleeding and surgery time were assessed in the duration of the surgical procedure. Pain level was measured using the Visual Analogue Scale (VAS), which is a $10 \mathrm{~cm}$ long straight line marked at each end with labels which anchor the scale. ${ }^{19}$ Also for each groups, postoperative analgesic requirements were evaluated.

\section{Statistical methods}

Statistical analyses were carried out using IBM PASW/SPSS software (v.18.0.0 2009, IBM Corporation, Somers, NY, USA). Statistical analyses were performed using the independent-sample t-test, chi-square and 
Mann-Whitney $U$ tests probability values ( $p$ values) less than 0.05 were regarded as significant.

\section{RESULTS}

The study population consisted of periodontal healthy 20 patients (8 males and 12 females) mean age $35.2 \pm 11.5$ years old. Study results are summarized in Table 1. Ten patients were treated by conventional surgery and other ten patients with soft tissue diode laser. There were no significant differences between both treatment types for age distribution $(p>0.05)$. Initially all patients were periodontal healthy and periodontal index values were similar between groups $(p=0.568)$.

Topical anesthesia was used in 7 of the patients for diode laser. However, all the patients in the conventional group wanted extra infiltrated anesthesia. The differences between the groups for anesthesia requirements were found statistically significant $(p<0.001)$.

There was significant association between treatment type and postoperative pain. The patients in test group had almost no postsurgical pain and they did not need analgesic. In the control group, the average pain level was found higher than test groups. The average postoperative pain were found 7.1 out of 10 and 2.4 out of 10 in the control and test groups respectively. The difference between in postoperative pain values were found significantly higher in the control groups. The bleeding rate following the surgery was assessed using the bleeding criteria established by the WHO. The average bleeding rates were 1.32 and 0.24 in the conventional and diode laser groups, respectively. In test group, intraoperative bleeding were found significantly lower. There was no significant difference for surgery time between the treatment types (Table 1). All patients were found healthy as periodontal. There were no significant difference for periodontal index values between the groups $(p=0.479)$.

Table 1.

\section{Statistical variables}

\begin{tabular}{|lccc|}
\hline Treatment & Laser $(\mathbf{n = 1 0})$ & $\begin{array}{c}\text { Conventional } \\
(\mathbf{n = 1 0})\end{array}$ & p-value \\
\hline $\begin{array}{l}\text { Anesthesia } \\
\text { needing }\end{array}$ & 7 & 10 & 0,001 \\
\hline $\begin{array}{l}\text { Postoperative } \\
\text { pain }\end{array}$ & $2.4 \pm 1.1$ & $7.1 \pm 1.9$ & 0,001 \\
\hline Bleeding rates & $0.24 \pm 0.2$ & $1.32 \pm 0.6$ & 0,001 \\
\hline Surgery time & $25.61 \pm 11.97$ & $27.10 \pm 12.83$ & 0,632 \\
\hline
\end{tabular}

\section{DISCUSSION}

In this study, we have compared the laser with conventional surgery. In the current study, the bleeding rate and pain level in the diode laser group were found less than that control group. This results was an agreement with other studies. ${ }^{17-19}$ Most of the patients in test group, surgery were performed without anesthesia but almost all patients in control group were injected infiltrative anesthesia. ${ }^{20,21}$

Conventional surgical have caused some problems like: surgical trauma, bleeding during surgery, postoperative pain and swelling, low satisfaction of patient. These problems can handle more easily with lasers. ${ }^{20}$ The use of laser reduces surgical trauma in soft tissue management with minimally invasive approach. But using laser extend the operating time. ${ }^{17}$ However, in this study there were found no statistically significant difference between the duration of operation time for each group.

We were observed that reduced bleeding during surgery and rapid postoperative hemostasis in test group. These results showed compatibility with other study. ${ }^{17-20}$

Other several studies evaluated that to compare lasers in the soft tissue surgical procedures with conventional surgery in young patients during orthodontic treatment but in this study we evaluated and compared this two type surgical procedure in adult patients needing cosmetic smile position gingivectomy. ${ }^{9,12,16,21}$ Therefore, there is no study in the literature similar to this study.

There are some limitations of this clinical study. The subjective quality of pain threshold may be the showed differences between individuals because the perception of pain is subjective. For this reason, we used VAS that is reliable and reproducible for patients. ${ }^{22}$

\section{CONCLUSION}

This study showed that the diode laser has more advantages than conventional surgery in the gingivectomy procedures. That includes a reduced intra operative and postoperative bleeding, a reduced pain sensitivity and recovery time. 


\section{REFERENCES}

1. Carranza FA, Hogan EL. Gingival enlargement. Newman MG, Takei HH and Carranza FA, editors. Carranza's clinical periodontology. Saunders; 2002. p. 279-96.

2. Seki K, Sato S, Asano $\mathrm{Y}$, Akutagawa H, Ito K. Improved pathologic teeth migration following gingivectomy in a case of idiopathic gingival fibromatosis. Quintessence Int 2010;41:543-5.

3. Foley TF, Sandhu HS, Athanasopoulos C. Esthetic periodontal considerations in orthodontic treatment--the management of excessive gingival display. J Can Dent Assoc 2003; 69: 368-72.

4. Parker S. Low-level laser use in dentistry. $\mathrm{Br}$ Dent $\mathrm{J}$ 2007;202:131-8.

5. de Santana-Santos T, de Souza-Santos a A, Martins-Filho PR, da Silva LC, de Oliveira ESED, Gomes AC. Prediction of postoperative facial swelling, pain and trismus following third molar surgery based on preoperative variables. Med Oral Patol Oral Cir Bucal 2013;18:e65-70.

6. Ozcelik O, Cenk Haytac M, Kunin A, Seydaoglu G. Improved wound healing by low-level laser irradiation after gingivectomy operations: a controlled clinical pilot study. J Clin Periodontol 2008;35:250-4.

7. Sarver DM. Use of the $810 \mathrm{~nm}$ diode laser: soft tissue management and orthodontic applications of innovative technology. Pract Proced Aesthet Dent 2006; 18: suppl 7-13.

8. Vescovi $\mathrm{P}$, Corcione L, Meleti M, Merigo E, Fornaini $\mathrm{C}$, Manfredi $\mathrm{M}$, et al. Nd:YAG laser versus traditional scalpel. A preliminary histological analysis of specimens from the human oral mucosa. Lasers Med Sci 2010;25:685-91.

9. Fornaini C, Rocca JP, Bertrand MF, Merigo E, Nammour S, Vescovi P. Nd:YAG and diode laser in the surgical management of soft tissues related to orthodontic treatment. Photomed Laser Surg 2007; 25:381-92.

10.Gontijo I, Navarro RS, Haypek P, Ciamponi AL, Haddad AE. The applications of diode and Er:YAG lasers in labial frenectomy in infant patients. J Dent Child (Chic) 2005;72:10-5.

11.Coluzzi DJ. Fundamentals of dental lasers: science and instruments. Dent Clin North Am 2004 48:75170.

12. Genovese MD, Olivi G. Use of laser technology in orthodontics: hard and soft tissue laser treatments. Eur J Paediatr Dent 2010;11:44-8.

13.Luomanen $M$. Experience with a carbon dioxide laser for removal of benign oral soft-tissue lesions. Proc Finn Dent Soc 1992;88:49-55.

14.Pirnat S. Versatility of an $810 \mathrm{~nm}$ diode laser in dentistry: An overview. J Laser Health Acad 2007; 4:1-9.
15.Shankar BS, T R, S NM, Reddy PS, Saritha G, Reddy JM. Chronic inflammatory gingival overgrowths: laser gingivectomy \& gingivoplasty. J Int Oral Health 2013;5:83-7.

16. Sobouti F, Rakhshan V, Chiniforush N, Khatami M. Effects of laser-assisted cosmetic smile lift gingivectomy on postoperative bleeding and pain in fixed orthodontic patients: a controlled clinical trial. Prog Orthod 2014;15:66.

17.Ize-lyamu IN, Saheeb BD, Edetanlen BE. Comparing the $810 \mathrm{~nm}$ diode laser with conventional surgery in orthodontic soft tissue procedures. Ghana Med J 2013;47:107-11.

18. Webert K, Cook RJ, Sigouin CS, Rebulla P, Heddle NM. The risk of bleeding in thrombocytopenic patients with acute myeloid leukemia. Haematologica 2006;91:1530-7.

19. Kersten $P$, White PJ, Tennant $A$. Is the pain visual analogue scale linear and responsive to change? An exploration using Rasch analysis. PLoS One 2014;9:e99485.

20. Kravitz ND, Kusnoto B. Soft-tissue lasers in orthodontics: an overview. Am J Orthod Dentofacial Orthop 2008;133:S110-4.

21.Kafas $P$, Stavrianos C, Jerjes W, Upile T, Vourvachis $M$, Theodoridis $M$, et al. Upper-lip laser frenectomy without infiltrated anaesthesia in a paediatric patient: a case report. Cases J 2009;2: 7138.

22.Grossi GB, Maiorana C, Garramone RA, Borgonovo A, Creminelli L, Santoro F. Assessing postoperative discomfort after third molar surgery: a prospective study. J Oral Maxillofac Surg 2007; 65:901-17.

\section{Corresponding Author:}

\section{Elif ÖNCÜ}

Necmettin Erbakan Üniversitesi

Diş Hekimliği Fakültesi

Periodontoloji AD

Karaciğan Mah. Ankara Cad.

No: 74/A, 42050, Karatay, Konya

Phone: +90 3322200020

Fax: +90332 2200045

E-mail: oncu.elif@hotmail.com 